\title{
PENGAWAS PENDIDIKAN AGAMA ISLAM DI KUTAI KARTANEGARA KALIMANTAN TIMUR
}

\section{Supervisor of Islamic Education in Kutai Kartanegara East Kalimantan}

\author{
Abdul Rahman Arsyad \\ Balai Penelitian dan Pengembangan Agama Makassar \\ Kantor Jl. A. P. Petta Rani No. 72 Makassar \\ E-mail: rahmanarsyad70@yahoo.com
}

Naskah diterima tanggal 31 Juli 2013. Naskah direvisi tanggal 2 Agustus 2013. Naskah disetujui tanggal 29 Agustus 2013

\begin{abstract}
Abstrak
Penelitian ini bertujuan untuk mengungkap kompetensi kepala madrasah di Kutai Kartanegara, dengan melihat aspek kepribadian, manajerial, akademik, evaluasi pendidikan, kelitbangan dan social pada pengawas PAI (Agama dan Disdik). Penelitian ini menggunakan metode kuantitatif, dalam analisis data selain angket/quesioner dengan pendekatan survei, berupaya untuk mengetahui tingkat kompetensi pengawas. Penelitian ini menggunakan metode kuantitatif dalam analisis data selain angket/ quesioner akan dianalisis secara deskriptif kuantitatif untuk mengetahui tingkat kompetensi pengawas PAI. Adapun data yang diperoleh melalui wawancara, study pustaka, dan dokumentasi. Hasil analisis disajikan lewat tabel dan grafik bagi data kuantitas dan naratif bagi data kualitas. Hasil penelitian ini menunjukkan bahwa tingkat kompetensi pengawas PAI Kementerian Agama dan Kementerian Disdik terkategori Sedang dengan nilai kompetensi 2.80, sedangkan nilai kompetensi rerata 55.
\end{abstract}

Kata kunci: kompetensi, pengawas, pendidikan agama Islam

\begin{abstract}
This study aims to reveal the competence of supervisior in Islamic schools (Madrasah) by looking at the aspects of personality, managerial, academic, educational evaluation, research and development, as well as social to the supervisor of Islamic Education (Religion Authority and Education Authority). The research methodology used was quantitative methods. In the data analysis, the questionnaires with survey approach were analyzed descriptively quantitative in order to identify to the competency level of the supervisors of Islamic education. The data obtained through interviews, literature study, and documentation. The results of the analysis are presented through tables and graphs for the quantitative data and narrative for qualitative data. The results of the research indicate that the supervisors' competency level of Islamic education of the Religious Affairs Ministry and Ministry of Education were in the fair category in which the competence score was 2.80 , whereas the average competence score was 55 .
\end{abstract}

Keywords: the competence, supervisor, Islamic education

\section{PENDAHULUAN}

$\mathrm{U}$ paya peningkatan kualitas pendidikan sedang gencar-gencarnya dilakukan oleh pemerintah saat ini. Berbagai usaha mulai dari pembaharuan kurikulum, perbaikan sarana prasarana, pelatihan guru, bantuan dana operasional sekolah, sampai pada peningkatan kualitas kepengawasan pendidikan. Eksistensi dan peran pengawas sekolah dalam aktivitas dan keberhasilan usaha pendidikan tidak diragukan lagi. Keberadaannya sangat penting karena merupakan mata rantai terakhir dan kunci dari proses manajemen. Robbins menyatakan bahwa kunci penting dari proses manajemen sekolah yaitu nilai fungsi pengawasan sekolah terletak terutama pada hubungannya terhadap perencanaan dan kegiatankegiatan yang didelegasikan (Nurkholis; 2003: 227). Selain itu, jika dilihat dari realitas kondisi : ada satu sektor yang selama ini kurang mendapat 
perhatian dari pemerintah, yaitu eksistensi, peran dan kompetensi pengawas. Keberadaan pengawas dituntut harus memiliki kompetensi yang lebih dibanding kemampuan tenaga pendidik dan tenaga kependidikan di Madrasah atau Sekolah. Tetapi kenyataannya bahwa lingkungan pendidikan agama di Kutai Kartanegara keberadaan pengawas belum sesuai yang diharapkan sehingga kualitas SDM, tanggung jawab dan kemampuannya perlu ditingkatkan.

Dari segi kualitas para pengawas masih banyak yang belum optimal pemahaman dan penguasaan terhadap tugas dan fungsinya, sedangkan melihat dari segi kuantitasnya jumlah pengawas belum memadai sehingga kinerja pelayanan pengawas pendais tidak terlihat secara optimal. Adapun yang menjadi isu aktual pengawas PAI di Kutai Kartanegara adalah, "beratnya beban kerja Pengawas dalam melaksanakan tugas kepengawasan".

Dalam Undang-undang RI nomor 20 tahun 2003 tentang Sistem Pendidikan Nasional, pasal 1 ayat (5) dinyatakan bahwa tenaga kependidikan adalah anggota masyarakat yang mengabdikan diri dan diangkat untuk menunjang penyelenggaraan pendidikan. Selanjutnya pada pasal 39 ayat (1) dinyatakan: tenaga kependidikan bertugas melaksanakan administrasi, pengelolaan, pengembangan, pengawasan dan pelayanan teknis untuk menunjang proses pendidikan pada satuan pendidikan. Dalam Peraturan Pemerintah Republik Indonesia Nomor 19 Tahun 2005 tentang Standar Pendidikan Nasional pasal 39 ayat (1) dinyatakan: pengawasan pada pendidikan formal dilaksanakan oleh pengawas satuan pendidikan. Surat Keputusan MENPAN Nomor 118 tahun 1996 yang diperbaharui dengan SK MENPAN Nomor 091/KEP/MENPAN/10/2001 tentang Jabatan Fungsional Pengawas Sekolah dan Angka Kreditnya dinyatakan pada Pasal 5 ayat (1); tanggung jawab pengawas sekolah yakni: (a) melaksanakan pengawasan terhadap penyelenggaraan pendidikan di sekolah sesuai dengan penugasannya dan; (b) meningkatkan kualitas proses belajar mengajar/ bimbingan dan hasil prestasi belajar/bimbingan siswa dalam rangka pencapaian tujuan pendidikan.

Tanggung jawab pertama mengindikasikan pentingnya supervisi manajerial sedangkan tanggung jawab yang kedua mengindikasikan pentingnya supervisi akademik. Hal ini dipertegas lagi dalam Peraturan Pemerintah Nomor 19 Tahun 2005 tentang Standar Pendidikan Nasional pasal 57 yang berbunyi; supervisi yang meliputi supervisi manajerial dan akademik dilakukan secara teratur dan berkesinambungan oleh pengawas atau penilik satuan pendidikan. Supervisi manajerial meliputi aspek pengelolaan dan administrasi satuan pendidikan, sedangkan supervisi akademik meliputi aspek-aspek pelaksanaan proses pembelajaran (penjelasan pasal 57). Pengawasan manajerial sasarannya adalah kepala sekolah dan staf sekolah lainnya, sedangkan sasaran supervisi akademik sasarannya adalah guru.

Peraturan Menteri Pendidikan Nasional RI Nomor 12 Tahun 2007 tentang Standar pengawas sekolah/Madrasah menegaskan bahwa seorang : harus memiliki enam kompetensi minimal, yaitu kompetensi kepribadian, supervisi manajerial, supervisi akademik, evaluasi pendidikan, penelitian dan pengembangan, serta kompetensi sosial.

Penelitian tentang kompetensi pengawas pendidikantelah banyak dilakukan baik berupa upaya peningkatan kualitasnya pengawas maupun kondisi kualitasnya. Penelitian kualitatif yang dilakukan oleh Marwan Seleuw di Jayapura tahun 2009 tentang pelaksanaan supervisi yang dilakukan oleh pengawas ditempuh melalui empat komponen yakni (1) proses/langkah supervisi meliputi; persiapan, pelaksanaan kegiatan supervisi dan tindak lanjut dan instrumen penilaian, (2) gaya supervisi yang digunakan yakni gaya demokrasi (3) teknik/ kompetensi Supervisi yang digunakan meliputi; teknik kunjungan langsung dan teknik tidak kunjungan langsung, dan (4) problem supervisi yang di hadapi meliputi problem dari guru, anak, kepala madrasah, pengawas, dan dari Departemen Agama. Hindun Anwar telah melakukan penelitian tentang hubungan kompetensi kepribadian dan kompetensi profesional pengawas pendidikan dalam batasan hubungan antara motivasi berpartisipasi dengan produktivitas kerja pengawas (Seleuw, 2009).

Penelitian berkaitan dengan peranan pengawas Dalam Meningkatkan kompetensi Guru Pendidikan Agama Islam (PAI) pada Madrasah Aliyah di Provinsi Gorontalo pada tahun 2011, menemukan bahwa meskipun kinerja pengawas dalam melaksanakan supervisi terhadap guru PAI pada Madrasah Aliyah di Provinsi Gorontalo sangat harmonis dan bersifat kooperatif sehingga turut membantu dalam meningkatkan kompetensi guru namun masih terdapat pengawas yang memiliki kompetensi rendah di bidang supervisi (Tali, 2011: 1415).

Penelitian yang dilakukan oleh Said Subhan Posangi, di Gorontalo menemukan bahwa faktor- 
faktor yang menjadi kendala pengawas untuk meningkatkan profesionalisme guru adalah berkaitan dengan kompetensi kepribadian, supervisi manajerial dan akademik, dan sosial. Kendalakendala itu, kata promovendus, antara lain: Masih adanya pengawas yang belum memiliki kesadaran dan rasa tanggungjawab yang tinggi dalam melaksanakan tugas. Masih adanya pengawas yang tidak memiliki kemampuan profesional di bidang kepengawasan (supervisi). Masih ada pengawas yang diangkat sekedar memperpanjang usia pensiun, sehingga kinerja rendah. Kurangnya sarana dan prasarana pengawas. Kesejahteraan : yang masih minim sehingga mempengaruhi kinerja pengawasan. Belum adanya motivasi agama yang dijunjung tinggi yakni keikhlasan untuk melakukan yang terbaik bagi orang lain. Balai Penelitian dan Pengembangan Kementerian Agama Makassar telah melakukan penelitian tentang Performansi pengawas Guru Agama Islam di beberapa Kabupaten di Sulawesi Tenggara pada tahun 2004 menemukan bahwa performansi Guru PAI tingkat Dasar dan Menengah tampak lebih rendah dari pada performansi Guru PAI. (Tim Balitbang Agama Makassar, 2004).

\section{PEMBAHASAN \\ Kondisi Pendidikan \\ Pengawas}

Pengawas PAI di Kutai Kartanegara, terdiri dari pengawas Agama dan Pengawas Diknas yang berlatar belakang pendidikan Sarjana (S1 dan S2). Hal ini menunjukkan bahwa jumlah pengawas PAI (Diknas) lebih banyak yaitu 23 orang dengan $63.8 \%$ dibanding pengawas PAI (Agama) hanya 13 orang atau $36.2 \%$.

\section{Lembaga Pendidikan dan Kedudukan}

Lembaga pendidikan S/M secara kuantitas terlihat ada perbedaan, baik fisik maupun non-fisik. Untuk madrasah di Kutai Kartanaegara dengan jumlah 108 (10.2\%), guru 973 (7.9\%), dan Siswa 10.495 (7.1\%), sedangkan sekolah berjumlah 969 (89.8\%), guru 11.200 (92.1\%), dan siswa 135.586 (92.9 \%). Hal ini menunjukkan bahwa, Sekolah Umum lebih dominan dibanding Madrasah dengan selisih $79.9 \%$. Sumber data diperoleh dari Kantor BPS : , Kementerian Agama Provinsi : dan Kabupaten : . Data tersebut menunjukkan bahwa, secara kuantitas minat masyarakat terhadap madrasah relatif sedikit dibanding Sekolah Umum.

\section{Identitas Responden}

Tingkat identitas responden dapat diamati berdasarkan pada variabel independen yaitu tempat tugas, jenis kelamin, mata pelajaran yang diawasi, dan usia angkatan, usia responden, lama menjabat, tingkat pendidikan, serta golongan/pangkat, disiplin ilmu, jabatan sebelum dan pendiklatan.

Teridentifikasi bahwa ada dua kategori tempat bertugas responden, yaitu kementerian agama 12 dan kementerian diknas 24. Dibanding keduanya, maka $66.6 \%$ pengawas diangkat oleh kementerian diknas. Berdasarkan jenis kelamin, tingkat kompetensi responden pria yang dominan, sedangkan MP. yang diawasi teridentifikasi ada dua kategori yaitu umum dan agama. Dari kedua kategori menunjukkan mata pelajaran agama yang lebih tinggi.

Teridentifikasi dari usia responden antara 40-59 tahun, namun pengangkatan pengawas baik agama maupun diknas dominan pada usia 56-59 (33.3\%), untuk usia angkatan dari 39-55 tahun, tampak 48-51 tahun, dan lama menjabat dari 1-16 tahun, terbanyak 4-6 tahun (53.3\%), serta pada latar belakang pendidikan pengawas dominan S1 dibanding S2.

Teridentifikasi golongan/pangkat responden, yaitu III/a-IV/b, rata-rata pengawas IV/a (56.7 \%) yang diangkat menjadi pengawas, untuk disiplin ilmu pengawas dominan pada umum saja (43.3 $\%)$, dan jabatan sebelum menjadi pengawas pada umumnya adalah Kamad (43.3\%), sedangkan para pengawas masih terdapat $66.7 \%$ yang belum pernah mengikuti kediklatan.

Variabel identitas responden, menunjukkan bahwa pengangkatan pengawas pendidikan Islam di Kutai Kartanegara dominan pada Disdik dengan golongan rata-rata IV/a yang berusia 56-59 tahun dengan usia angkatan 4-6 tahun, sedangkan pendidikan terakhir responden dominan S1. Namun terdapat 66.7 \% pengawas yang belum pernah mengikuti diklat kepengawasan.

\section{Kompetensi Pengawas \\ Tingkat Kompetensi}

Setelah dilakukan analisis deskriptif terhadap hasil isian angket pengawas, maka diperoleh gambaran bahwa secara keseluruhan menunjukkan bahwa tingkat kompetensi pengawas PAI terkategori sedang. kompetensi rata-rata responden mencapai nilai rerata 55 dari standar ideal yang ditentukan (skor maksimal: 325), meskipun terdapat responden 
yang tingkat kompetensinya hanya mencapai nilai minimal 41, namun tingkat kompetensi tertinggi mencapai nilai maksimal 67 dari skor maksimal.

\begin{tabular}{lr}
\multicolumn{2}{c}{ Tabel 1. Tingkat kompetensi } \\
\hline $\mathrm{N}$ & \multicolumn{1}{c}{ Total } \\
Range & 30 \\
Min & 84 \\
Maks & 134 \\
Rerata & 218 \\
Std Dev & 1.799 \\
Skor Maks & 22.115 \\
Komp Min & 325 \\
Komp Maks & $\mathbf{4 1}$ \\
Komp Rerata & $\mathbf{6 7}$ \\
\hline
\end{tabular}

Tingkat kompetensi tersebut dapat dibuktikan dari hasil analisis implementasi responden terhadap indikator-indikator kompetensi kepribadian, manajerial, akademik, evaluasi pendidikan, kelitbangan, dan sosial.

Kepribadian semacam ini dapat dikembangkan melalui tahapan mengenal diri sendiri, mengembangkan diri dan memberdayakan diri sendiri, walaupun selanjutnya pengawas juga diharapkan dapat mengenal, mengembangkan dan memberdayakan orang lain. (Dirjen Peningkatan Mutu pendidikan dan Kependidikan Diknas, 2009:1-2)

Kompetensi Kepribadian, dari 4 indikator hanya tiga responden yang mengimplementasikan dengan tepat, yaitu $100 \%$. Indikator tersebut adalah kreatifitas kerja dan memecahkan masalah kepengawasan, rasa ingin tahu yang tinggi, dan memotivasi diri untuk bekerja. Sedangkan indikator komitmen kerja dan tanggung jawab telah diimplementasikan dengan tepat oleh sejumlah 63.3 $\%$ responden.

Supervisi manajerial menitik beratkan pada pengamatan pada aspek-aspek pengelolaan dan administrasi sekolah yang berfungsi sebagai pendukung (supporting) terlaksananya pembelajaran. (Dirjen Peningkatan Mutu pendidikan dan Kependidikan Diknas, 2009: 15).

Kompetensi Manajerial, terdapat delapan indikator, namun yang tampak telah diimplementasikan dengan tepat oleh sejumlah lebih
$100 \%$ responden. Indikator tersebut adalah metode supervisi, prinsip kepengawasan, pengawasan berdasarkan visi, misi, tujuan dan program pensisikan. Sedangkan indikator membantu Kepala Madrasah menemukan kelebihan dan kekurangan pelaksanaan tugas pokok telah diimplementasikan dengan tepat oleh sejumlah $66,7 \%$ responden.

kompetensi supervisi akademik adalah kemampuan pengawas sekolah dalam melaksanakan pengawasan akademik yakni menilai dan membina guru dalam rangka mempertinggi kualitas proses pembelajaran yang dilaksanakannya, agar berdampak terhadap kualitas hasil belajar siswa. (Dirjen Peningkatan Mutu pendidikan dan Kependidikan Diknas, 2009: 2-3). kompetensi Supervisi Akademik, terdapat delapan indikator, responden yang tampak mengimplementasikan dengan tepat $100 \%$, pada tiga indikator, yaitu memahami perkembangan MP dan proses pembelajaran yang ditugaskan, serta membimbing guru menyusun silabus. Sedangkan indikator media : dan fasilitas pembelajaran, dalam hal merawat media telah diimplementasikan dengan tepat hanya oleh $73,3 \%$ responden.

Mengacu pada Peraturan Menteri Pendidikan Nasional (Permen) Nomor 20 Tahun 2007 Tentang Standar Penilaian pendidikan, maka penilaian hasil belajar peserta didik pada jenjang pendidikan dasar dan menengah didasarkan pada prinsip-prinsip sebagai berikut: sahih, objektif, adil, terpadu, terbuka, menyeluruh dan berkesinambungan, sistimatis, beracuan kriteria, dan akuntabel. (Dirjen Peningkatan Mutu pendidikan dan Kependidikan Diknas, 2009: 32-34).

Kompetensi evaluasi pendidikan, dari enam indikator yang telah diimplementasikan dengan tepat $100 \%$, terdapat pada indikator pelaksanaan pembelajaran dalam memantau pelaksanaan pembelajaran yang dilakukan guru mata pelajaran. Sedangkan indikator membina guru dalam memanfaatkan hasil penilaian telah diimplementasikan dengan tepat oleh sejumlah 46, $6 \%$ responden.

Kegiatan pengembangan profesi pengawas sekolah yang ditetapkan berdasarkan peraturan yang berlaku saat ini. Karya pengembangan profesi : dapat berupa: membuat karya tulis ilmiah (KTI), menemukan teknologi tepat guna, membuat alat peraga/bimbingan, menciptakan karya seni, dan mengikuti kegiatan pengembangan kurikulum. 
(Dirjen Peningkatan Mutu pendidikan dan Kependidikan Diknas, 2009: 15).

Kompetensi Kelitbangan, dari delapan indikator hanya satu indikator yang telah diimplementasikan responden dengan tepat 73,4 $\%$. yaitu mengidentifikasi masalah kepengawasan. Sedangkan indikator pengembangan profesi dalam menemukan teknologi tepat guna telah diimplementasikan dengan tepat oleh sejumlah 16,7 $\%$ responden.

Kompetensi Pengawas mendasari seluruh kompetensi lainnya, karena berkaitan dengan aspek nilai dan sikap serta motivasi dan komitmen. (Dirjen Peningkatan Mutu pendidikan dan Kependidikan Diknas, 2009:1).kompetensi sosial,daritigaindikator terdapat 2 indikator yang telah diimplementasikan dengan tepat $100 \%$, yaitu membangun kemitraan dalam meningkatkan kualitas diri pada guru mata pelajaran dan membangun kemitraan dalam rangka melaksanakan tugas kepengawasan pada Kemenag/Kemediknas, sesama pengawas, dan guru MP. Sedangkan indikator Aktif dalam kegiatan asosiasi pengawas, terdapat $96 \%$ responden yang mengimplementasikan dengan tepat.

Dari hasil analisis deskriptif dan analisis implementasi diatas, menunjukkan bahwa dari beberapa indikator pada setiap kompetensi, tampak yang mengimplementasikan secara maksimal, yaitu padakompetensi kepribadian, manajerial, akademik, evaluasi pendidikan, dan sosial. Sedangkan pada kompetensi kelitbangan secara keseluruhan belum mengimplementasikan secara maksimal.

Tingkat kompetensi responden dapat diamati berdasarkan pada variabel independen yaitu tempat tugas, jenis kelamin, mata pelajaran yang diawasi, dan usia angkatan, usia responden, lama menjabat, tingkat pendidikan, serta golongan/pangkat, disiplin ilmu, jabatan sebelum dan pendiklatan.

Teridentifikasi bahwa ada dua kategori tempat bertugas responden, yaitu kementerian agama dan kementerian diknas. Dibanding keduanya, maka tingkat kompetensi responden yang diangkat di kementerian diknas lebih tinggi. Berdasarkan jenis kelamin, tingkat kompetensi responden wanita yang dominan, sedangkan MP. yang diawasi teridentifikasi ada dua kategori yaitu umum dan agama. Dari kedua kategori menunjukkan mata pelajaran umum lebih tinggi. Jelasnya pada rincian tabel, sebagai berikut:
Tabel 2. Tingkat Kompetensi Responden Berdasarkan Tempat Tugas, Jenis Kelamin, dan MP. yang diawasi

\begin{tabular}{ccccc}
\hline No & Identitas & Jenis & Tingkat & Kategori \\
\hline \multirow{2}{*}{ 1. } & Tempat & Kemenag & 2.60 & Sedang \\
& Tugas & Disdik & 2.65 & Sedang \\
2. & Jenis & Pria & 2.62 & Sedang \\
& Kelamin & Wanita & 2.93 & Sedang \\
3. & MP. yang & Agama & 2.63 & Sedang \\
& diawasi & Umum & 2.89 & Sedang \\
\hline
\end{tabular}

Teridentifikasi bahwa ada lima kategori usia responden, yaitu 40-43, sampai 56-59. Dibanding keempatnya, maka tingkat kompetensi responden yang usia 52-55 lebih tinggi. Berdasarkan usia angkatan ada lima kategori 39-41 sampai 52-55, maka tingkat kompetensi responden yang usia 45-47 lebih tinggi, sedangkan lama menjabat teridentifikasi ada lima kategori dari 1-3 sampai 13-16 tahun, maka tingkat kompetensi responden lama menjabat 4-6 tahun yang lebih tinggi, untuk pendidikan terakhir ada dua kategori yaitu S1 dan S2. Dari kedua kategori menunjukkan S1 (strata satu) yang lebih tinggi. Jelasnya pada rincian tabel sebagai berikut:

Tabel 3. Tingkat Kompetensi Responden

Berdasarkan Usia Responden, Usia Angkatan,

Lama Menjabat, dan pendidikan terakhir

\begin{tabular}{ccccc}
\hline No & Identitas & Jenis & Tingkat & Kategori \\
\hline 1. & Usia & $40-43$ & 2.67 & sedang \\
& Responden & $44-47$ & 2.3 & sedang \\
& & $48-51$ & 2.50 & sedang \\
& & $52-55$ & 2.71 & sedang \\
& & $56-59$ & 2.7 & sedang \\
2. & Usia & $39-41$ & 2.50 & sedang \\
& Angkatan & $42-44$ & 2.6 & sedang \\
& & $45-47$ & 3 & sedang \\
& & $48-51$ & 2.62 & sedang \\
& & $52-55$ & 2.6 & sedang \\
3. & Lama & $1-3$ & 2.43 & sedang \\
& Menjabat & $4-6$ & 2.71 & sedang \\
& & $7-9$ & 2.6 & sedang \\
& & $10-12$ & 2.5 & sedang \\
& & $13-16$ & 3.5 & tinggi \\
4. & & S1 & 2.58 & sedang \\
& & S2 & 2.50 & sedang \\
\hline
\end{tabular}

Teridentifikasi bahwa ada tiga kategori golongan/pangkat responden, yaitu III/b sampai 
IV/a,. Dibanding dari tiga golongan, maka tingkat kompetensi responden yang golongan/pangkat III/b lebih tinggi. Berdasarkan disiplin ilmu ada empat kategori umum saja, agama saja, umum sesuai bidang studi, dan agama sesuai bidang studi, maka tingkat kompetensi responden disiplin ilmu agama sesuai bidang studi yang diawasi lebih tinggi, sedangkan jabatan sebelum teridentifikasi mulai seksi, pejabat, Kamad, dan guru, maka tingkat kompetensi responden seksi lebih tinggi, untuk kediklatan ada lima kategori yaitu belum pernah sampai empat kali. Dari kelima kategori menunjukkan bahwa dua dan tiga kali yang lebih tinggi. Jelasnya pada rincian tabel sebagai berikut:

Tabel 4. Tingkat Kompetensi Responden Berdasarkan Golongan/Pangkat, Disiplin Ilmu, Jabatan Sebelum, dan Kediklatan

\begin{tabular}{ccccc}
\hline No & Identitas & \multicolumn{1}{c}{ Jenis } & Tkt & Kategori \\
\hline 1. & Gol/Pangkat & III/b & 2.60 & sedang \\
& & III/c-III/d & 2.50 & sedang \\
& & IV/a & 2 & sedang \\
2. & Disiplin Ilmu & Umum saja & 2.46 & sedang \\
& & Agama saja & 2.80 & sedang \\
& & Umum sesuai & 2.66 & sedang \\
& & Agama sesuai & 3 & sedang \\
3. & Jabatan & Seksi & 2.70 & sedang \\
& Sebelum & Pejabat & 2.67 & sedang \\
& & Kamad & 2.61 & sedang \\
& & Guru & 2.5 & sedang \\
4. & Diklat & Belum pernah & 2.55 & sedang \\
& & Sekali & 2.80 & sedang \\
& & Dua kali & 3 & sedang \\
& & Tiga kali & 3 & sedang \\
& & Empat kali & 2.5 & sedang \\
\hline
\end{tabular}

Setelah dilakukan analisis deskriptif dan implementasi responden terhadap semua kompetensi pengawas dan indikator pada masingmasing kompetensi, maka secara keseluruhan menunjukkan bahwa tingkat kompetensi pengawas PAI terkategori sedang. Ada tiga tingkat kompetensi terkategori tinggi yaitu kompetensi kepribadian, manajerial, dan kompetensi sosial, kemudian kompetensi yang terkategori sedang ada dua yaitu kompetensi supervisi akademik dan evaluasi pendidikan. Sedangkan, kompetensi kelitbangan terhadap pengawas PAI menunjukkan bahwa tingkat kompetensinya terkategori rendah.
Tabel 5. Total kompetensi Pengawas PAI

\begin{tabular}{clcc}
\hline NO & KOMPETENSI & TINGKAT & KATEGORI \\
\hline 1 & Kepribadian & 3.18 & Tinggi \\
2 & Sup. Manajemen & 3.09 & Tinggi \\
3 & Sup. Akademik & 2.97 & Sedang \\
4 & Evaluasi pendidikan & 2.94 & Sedang \\
5 & Litbang & 1.35 & Rendah \\
6 & Sosial & 3.26 & Tinggi \\
Total & & $\mathbf{2 . 8 0}$ & Sedang \\
\hline
\end{tabular}

\section{Korelasi Antara Identitas Dan Tingkat \\ Kompetensi Pengawas \\ Normalitas Data}

Secara metodologis, analisis normalitas data dilakukan sebelum analisis korelasi. Variabel identitas responden dan variable tingkat kompetensi yang diuji tes normalitasnya dengan menggunakan SPSS agar dapat diketahui signifikan normalitas data. Sedangkan standar signifikan normalitasnya yang digunakan adalah $\alpha=0,05(\mathrm{p}>0,05)$.

Metode uji Kolmogrov-Smirnov mengindikasikan, bahwa dari tujuh variabel yang diuji datanya, hanya dua variabel yang terindikasi normal secara signifikan, yaitu usia responden dan lama bertugas. $\mathrm{p}=0.20>\alpha=0,05$, dan $\mathrm{p}=0.09>a=0,05$ Sementara lima data variabel yang terindikasi tidak tersebar normal, yaitu: pendidikan terakhir : $\mathrm{p}=0,00$ $<\alpha=0,05$, Gol/Pangkat: $p=0,00<\alpha=0,05$, disiplin ilmu: $\mathrm{p}=0,00<\alpha=0,05$, jabatan sebelum: $\mathrm{p}=0,00$ $<\alpha=0,05$, usia angkatan: $p=0,00<\alpha=0,05$.

Pada variable kompetensi pengawas secara total. Dengan analisis dan standar signifikansi yang sama $\alpha=0,05(\mathrm{p}>0,05)$. Hasil uji tes normalitas mengindikasikan, bahwa kompetensi yang datanya terdistribusikan normal yaitu: kepribadian $\mathrm{p}=0.20$ $>\alpha=0.05$, manajerial $\mathrm{p}=0.20>\alpha=0.05$, akademik $\mathrm{p}=0.20>\alpha=0.05$, evaluasi pendidikan $\mathrm{p}=0.18>\alpha$ $=0.05$, dan sosial $\mathrm{p}=0.08>\alpha=0.05$. Sedangkan satu variable yang terindikasi tidak terdistribusi normal, yaitu kompetensi Litbang: $\mathrm{p}=0.00>\alpha=0.05$.

\section{Uji Korelasi}

Uji korelasi ini, untuk mengetahui signifikan korelasi antara variabel identitas responden dengan variable komponen kompetensi pengawas. hasil uji normalitas data, hanya variable usia responden dan lama bertugas yang terdistribusi normal, serta pada variable kompetensi yang terdistribusi normal yaitu, variable kepribadian, manajerial, akademik, 
evaluasi pendidikan, dan sosial, yang layak dianalisis korelasi.

Simbol Variabel: $\mathrm{X} 1=$ usia responden dan $\mathrm{Y} 1=$ kompetensi $\quad$ kepribadian, $\quad \mathrm{Y} 2=$ kompetensi manajerial, Y3=kompetensi akademik, Y4= kompetensi evaluasi pendidikan, Y5=kompetensi sosial.

Hipotesis Analisis: jenis analisis korelasi yang digunakan adalah korelasi persial, sedangkan uji analisis korelasi menggunakan SPSS dengan : pearson correlation pada standar signifikansi $\alpha=$ 0.05 .

$\mathrm{H} 0=$ tidak ada hubungan yang signifikan antara variable identitas dengan variable kompetensi. (H0 diterima pada : $\alpha$ hitung $>\alpha$ standar $=0.05$ ).

$\mathrm{Ha}=\mathrm{ada}$ hubungan yang signifikan antara variable identitas dengan variable kompetensi. (Ha diterima pada: $\alpha$ hitung $<\alpha$ standar $=0.05$ ).

Kekuatan korelasi diukur berdasarkan kriteria sebagai berikut:

a. $0.00-0.20$ : sangat lemah

b. $0.21-0.04$ : korelasi lemah

c. $0.41-0.60$ : korelasi sedang

d. $0.61-0.80$ : kuat

e. $0.81-1.00$ : sangat kuat

Sementara positif $(+)$ bermakna korelasi satu arah, sedangkan negatif (-) bermakna korelasi dua arah. Hasil analisis pada tingkat usia responden dan lama menjabat, tidak berpengaruh secara signifikan terhadap kelima kompetensi responden. Semakin tinggi tingkat usia responden dan lama menjabat sebagai pengawas, tidak mempengaruhi pada tingkat kompetensinya. Hubungan variable independen terhadap variabel dependen tampak terbalik, tingkat kompetensi responden yang mempengaruhi usia dan lama menjabat sebagai pengawas, meskipun korelasinya tidak signifikan. Hal ini menunjukkan bahwa, usia responden dan lama menjabat sebagai : dikarenakan memiliki tingkat kompetensi.

Kondisi tersebut dapat dibuktikan pada responden yang berusia 52-55 tahun yang memiliki tingkat kompetensi yang tinggi pada aspek sosial dan kepribadian, sedangkan aspek manajerial, akademik, dan evaluasi pendidikan, responden berkompetensi sedang. Untuk responden yang menjabat antara 4-9 tahun memiliki tingkat kompetensi yang tinggi pada aspek sosial, sedangkan yang memiliki tingkat kompetensi sedang yaitu aspek kepribadian, manajerial, akademik, dan evaluasi pendidikan.
Tabel 6. Tingkat Kompetensi Kepribadian, Manajerial, Akademik, Sosial

Evaluasi pendidikan Pengawas Berdasarkan Usia dan Lama Menjabat

\begin{tabular}{|c|c|c|c|c|c|c|c|c|c|c|}
\hline \multirow{2}{*}{ Usia } & \multicolumn{2}{|c|}{$\begin{array}{l}\text { Kepri- } \\
\text { badian }\end{array}$} & \multicolumn{2}{|c|}{$\begin{array}{c}\text { Mana- } \\
\text { jerial }\end{array}$} & \multicolumn{2}{|c|}{$\begin{array}{l}\text { Aka- } \\
\text { demik }\end{array}$} & \multicolumn{2}{|c|}{$\begin{array}{c}\text { Eva. } \\
\text { Pendidik }\end{array}$} & \multicolumn{2}{|c|}{ Sosial } \\
\hline & 量 & 崩 & 晃 & $\stackrel{0}{5}$ & 晃 & $\stackrel{0}{\underline{L}}$ & 音 & 它 & 点 & $\stackrel{\mathrm{E}}{\mathrm{E}}$ \\
\hline $40-43$ & 2.83 & S & 2.82 & S & 2.83 & S & 2.5 & $S$ & 3.5 & $\mathrm{~T}$ \\
\hline $44-47$ & 2.6 & S & 2.4 & S & 2.5 & S & 2.2 & $S$ & 2.9 & S \\
\hline $48-51$ & 3.1 & $\mathrm{~T}$ & 2.9 & S & 2.8 & S & 2.8 & S & 3.1 & $\mathrm{~T}$ \\
\hline $52-55$ & 2.92 & S & 3.07 & $\mathrm{~T}$ & 2.92 & S & 3.07 & $\mathrm{~T}$ & 3.07 & $\mathrm{~T}$ \\
\hline $56-59$ & 3.1 & $\mathrm{~T}$ & 3 & S & 2.8 & S & 2.9 & $\mathrm{~S}$ & 3.3 & $\mathrm{~T}$ \\
\hline \multicolumn{11}{|c|}{ Lama Menjabat } \\
\hline $1-3$ & 3 & S & 2.88 & S & 2.75 & S & 2.5 & S & 3.25 & $\mathrm{~T}$ \\
\hline $4-6$ & 3 & S & 3 & S & 2.92 & S & 3.07 & $\mathrm{~T}$ & 3.07 & $\mathrm{~T}$ \\
\hline $7-9$ & 3.3 & $\mathrm{~T}$ & 2.9 & S & 2.5 & S & 2.7 & S & 3.5 & $\mathrm{~T}$ \\
\hline $10-12$ & 2.5 & S & 3 & S & 3 & S & 3 & S & 3 & $\mathrm{~T}$ \\
\hline $13-16$ & 3.5 & $\mathrm{~T}$ & 3.5 & $\mathrm{~T}$ & 3.5 & $\mathrm{~T}$ & 3.5 & $\mathrm{~T}$ & 3.5 & $\mathrm{~T}$ \\
\hline
\end{tabular}

\section{PENUTUP}

Tingkat kompetensi pengawas PAI, terukur lewat analisis deskripsi, implementasi responden dan secara cross tabulasi, menunjukkan bahwa kompetensi pada pengawas, baik Kemenag maupun Disdik, secara keseluruhan terkategori "sedang" (2.80) dengan kompetensi rerata 55. Dari keenam kompetensi, ada empat kompetensi yang terkategori "tinggi" yaitu kepribadian, supervisi manajerial, dan sosial. Sedangkan yang terkategori "sedang", yaitu kompetensi supervisi akademik, dan evaluasi pendidikan. Namun, hanya kompetensi Litbang yang terkategori "Rendah". Hal ini dibuktikan, dalam mengimplementasikan secara keseluruhan indikator kompetensi belum tepat. Pada kompetensi supervisi akademik yang perlu ditingkatkan adalah membimbing guru merawat media dan fasilitas pembelajaran, sedangkan kompetensi evaluasi adalah membina guru dalam memanfaatkan hasil penilaian. Untuk kompetensi Litbang, perlu adanya perbaikan secara keseluruhan dalam pengimplementasian kompetensi.

Hasil analisis tingkat kompetensi pengawas berdasarkan identitas responden berdasarkan usia responden idealnya 48-51 tahun, ideal lama menjabat sebagai pengawas 13-16 tahun, untuk pendidikan terakhir pengawas S1 dengan bergolongan IV/a, sedangkan tingkat kompetensi responden jabatan sebelum menjadi pengawas, dominan pada jabatan 
Seksi. Analisis tidak layak dilanjutkan karena semua variable yang diduga saling berhubungan tidak terdistribusi normal.

\section{UCAPAN TERIMA KASIH}

Penelitian ini dibiayai oleh DIPA Litbang Agama Makassar Tahun 2012. Ucapan terima kasih diperuntukkan kepada para informan di lapangan khususnya para responden, juga terima kasih kepada teman-teman di bidang pendidikan dan keagamaan pada Balai Penelitian Dan Pengembangan Agama Makassar atas kebersamaan kita selama ini.

\section{DAFTAR PUSTAKA}

Direktorat Jenderal Peningkatan Mutu Pendidik Dan Tenaga Kependidikan Departemen Pendidikan Nasional 2009 Bahan Belajar Mandiri Kelompok Kerja pengawas sekolah Dimensi Kompetensi Keperibadian dan Dimensi Kompetensi Sosial Bagian II Jakarta: Direktorat Jenderal Peningkatan Mutu Pendidik Dan Tenaga Kependidikan Departemen Pendidikan Nasional. 2009 Bahan Belajar Mandiri Kelompok Kerja pengawas sekolah Dimensi Kompetensi Keperibadian dan Dimensi Kompetensi Sosial Jakarta: Direktorat Jenderal Peningkatan Mutu Pendidik Dan Tenaga Kependidikan Departemen Pendidikan Nasional. 2009 Bahan Belajar Mandiri Kelompok Kerja pengawas sekolah Dimensi kompetensi Supervisi Manajerial Jakarta: Direktorat Jenderal Peningkatan Mutu Pendidik Dan Tenaga Kependidikan Departemen Pendidikan Nasional.

2009 Bahan Belajar Mandiri Kelompok Kerja pengawas sekolah Dimensi Kompetensi Supevisi Akademik Jakarta: Direktorat Jenderal Peningkatan Mutu Pendidik Dan Tenaga Kependidikan Departemen Pendidikan Nasional.
2009 Bahan Belajar Mandiri Kelompok Kerja pengawas sekolah Dimensi Kompetensi Penelitian dan pengembangan Jakarta: Direktorat Jenderal Peningkatan Mutu Pendidik Dan Tenaga Kependidikan Departemen Pendidikan Nasional.

2009 Bahan Belajar Mandiri Kelompok Kerja pengawas sekolah Dimensi Evaluasi pendidikan Jakarta: Direktorat Jenderal Peningkatan Mutu Pendidik Dan Tenaga Kependidikan Departemen Pendidikan Nasional.

Keputusan Menteri Pendayagunaan Aparatur Negara No. 118/1996 yang dirubah dengan Keputusan Menpan No. 91/2001 tentang Jabatan Fungsional Pengawas Sekolah dan Angka Kreditnya.

Nurkolis, Drs. M.M. 2003 Manajemen Berbasis Sekolah Jakarta: Grasindo

Peraturan Menteri Pendidikan Nasional No. 12 Tahun 2007 tentang Standar pengawas sekolah/Madrasah.

Peraturan Pemerintah Republik Indonesia No. 19 Tahun 2005 tentang Standar Nasional Kependidikan.

Salinan Lembaran Negara Republik Indonesia Tahun 2001 tentang SK MENPAN Nomor 091/KEP/MEN.PAN/10/2001 tentang Jabatan Fungsional Pengawas Sekolah dan Angka Kreditnya

Seleuw, Marwan. 2009. kompetensi Supervisi pengawas. Jayapura.

Tim Balai Litbang Agama Makassar 2004 Laporan Penelitian Performansi Pengawas dan Guru PAI di Sekolah Umum. di Sulawesi Tenggara

Tali, Adirun T. 2011. Peran pengawas dalam Meningkatkan Kompetensi Guru PAI. Makassar: UIN Alauddin.

Transmedia Pustaka 2003 Undang-Undang Republik Indonesia Nomor 20 Tahun 2003 tentang Sistem Pendidikan Nasional dan UndangUndan Republik Indonesia Nomor 19 Tahun 2005 tentang Guru dan Dosen, Jakarta Selatan: Transmedia Pustaka. 